\title{
The challenges of rapid urbanization on sustainable development of Nyanya, Federal Capital Territory, Abuja, Nigeria \\ *15UNDAY P.EJARO AISHA ABUBAKAR
}

\author{
Depantment of GeographyandEnvironmental Management, \\ University of Abuja, Abuja, Nigeria. (ejarosp1@yahoo.com) \\ *Correspondence Author:E-mail: ejarosp1@yahoo.com
}

Key Words: Rapid urbanization, false urbanization, infrastructural facilities and services , land use, land cover, sustainable development

\begin{abstract}
The study examines the challenges of rapid urbanization on the sustainable development of Nyanya, Abuja. An interesting finding of the study is that the primary factor for the rapid urbanization of Nyanya within a short period of time is migration. The consequence of this rapid urbanization and population rise within a short period is that infrastructural facilities and services are grossly inadequate to cater for the population. The study reveals that there is inadequate good quality housing, poor waste management, inadequate electric power supply, inadequate good quality domestic water supply, inadequate and unaffordable health care facilities, poor environmental health and traffic congestion on the Abuja city-Nyanya-Maraba-Keffi road. These challenges do not commend Nyanya as a satellite town on the path of sustainable urban development. Recommendations proffered to address these challenges include; urgent need for the Abuja Federal Capital Territory Administration to embark on urban renewal of Nyanya. Adequate infrastructural facilities and services should be provided for the residents. Mechanism for periodic review and upgrading should be put in place to ensure a qualitative built urban environment, with adequate resources and facilities to support a sustainable healthy living and economic progress of the residents of Nyanya.@JASEM
\end{abstract}

DOI: http://dx.doi.org/10.4314/jasem.v17i2.13

Urbanization is the physical growth of urban areas as a result of rural migration and even suburban concentration into cities. It largely occurs because of the movement of people from communities concerned chiefly or solely with agriculture, to other communities generally larger, whose activities are primarily centered in government, trade, manufacture, or allied interests. It is also seen as the movement of populations from rural to urban areas, and the resulting increasing proportion of a population that resides in urban, rather than rural areas.

Various theories of urbanization have been put forward to explain urbanization, its pattern and trend globally. Of the many discussions, the four theories of urbanization reviewed by Peng et. al. (2012) covering different era is captivating. These are; the theories of self-generated or endogenous urbanization, the modernization theory, the dependency/world system perspective and the Global city perspectives.

It must be kept in mind that urbanization is a two way process, because it involves not only movement from villages to cities, but also changes from agricultural occupation to business, trade, services and other professions. Urbanization is not about simply increasing the number of urban residents or expanding the area of cities. More importantly, it's about a complete change from rural to urban style in terms of industry structure, employment, living environment and social security (Wikipedia, 2012)

In the last 50 years, developing countries have experienced rapid and unprecedented urban growth due largely to industrialization and changes in the global economy (Cohen, 2006). At the beginning of

\section{*Correspondence Author:E-mail: ejarosp1@yahoo.com}


the 20th century, just 16 cities in the world had populations of more than a million of people, the vast majority of which were in industrialized countries. Today, at the beginning of the 21 st century, there are around 400 cities in the world with populations over a million people, $75 \%$ of which are in low and middle income countries. The population increase in urban areas is mostly occurring in the developing countries of Latin America, East Asia and the Pacific, South Asia, Central Asia, Middle East and North Africa and the Sub- Saharan Africa with middle and low incomes (Wikipedia, 2012). Spatially, in the 1950 s, 23 of the 35 world's largest urban agglomerations were found in more developed countries but by 1985, 23 of the 35 world's largest urban agglomerations were located in less developed countries (Agbola, 2005). At the turn of the $21^{\text {st }}$ Century, 17 of the world's 20 largest cities were projected to be in third world countries (Dogan and Kasarda, 1989).

According to the UN State of the World Population 2007 report, sometime in the middle of 2007, the majority of people worldwide were living in towns or cities, for the first time in history; this is referred to as the arrival of the "Urban Millennium" or the 'tipping point'. In regard to future trends, it is estimated 93\% of urban growth will occur in developing nations, with $80 \%$ of urban growth occurring in Asia and Africa (Ankerl, 1986; UNFPA, 2007; cited in Wikipedia, 2012).

Rapid urbanization growth in African countries reflects substantial migration to cities from rural areas and also natural population increase through increased births over deaths among city residents. Of the two major sources of urban population growth, in some countries natural increase plays the greater role while in some others migration from rural areas contributes more. Cincotta and Engelman (1997) observe that some cities are growing two or three times faster than the country's overall population, reflecting massive migration to such cities. Agbola (2005) notes that what is ironic and confounding, however, is that the urbanization process in the more developed countries took many decades, permitting a gradual emergence of economic, social and political systems to tackle the problems of transformations. But the pattern of urban agglomerations in the less developed countries are occurring more rapidly against a background of higher population growth, less developed economic, social and political systems. This process of urbanization and city growth in developing countries has been described by Hartshon (1992) cited in Agbola (2005) as "false urbanization". According to him, it is false urbanization in the sense that the process is primarily driven by demographic forces, particularly ruralurban migration, rather than by dynamic economic and industrial forces.

In the context of the preceding description of the process of urbanization in developing countries, false urbanization is the experience in Nigeria. There is hardly a city in Nigeria where water supply and electricity is regular, affordable housing for every resident, accessible good health services to all, where waste is scientifically disposed, accessible and affordable good transport etc. the urban centres, rather than providing comfort and being centres of arts and civilization, have become urban jungles (Agbola, 2005). The challenges to this false urbanization include, high unemployment, environmental degradation, deficiencies in urban services and inadequate housing, deterioration of existing infrastructure, inaccessibility to key resources, social vices, crime and violence (IHDP, 2005).

There is a negative relationship between uncontrolled and unplanned urbanization and sustainable development. Rapid urbanization, if left unplanned as per the experiences of many developing countries, often leads to unsustainable development and increases in poverty, crime and insecurity in towns and cities. One of the continent's main developmental challenges for the first two decades of this new millennium would be how to successfully manage its urbanization for sustainable economic development and social emancipation (Falade, 2005).

As pointed out earlier, developing countries are experiencing a faster rate of urbanization than the developed world; this is manifested more in African where the annual average growth rates were estimated to be $4.7 \%$ and $4.6 \%$ between the period of 1960 and 1980, and 1980 to 2000 respectively (UN, 2006). Studies have shown though that in developing countries, urban growth and expansion directly leads to rapid population growth and is attributed to migration. The Federal Capital Territory (FCT), Abuja, Nigeria, experiences an annual growth rate of $9.28 \%$, annually, as against the National economic growth rate of $4.8 \%$ (Ejaro,2009) This rapid urbanization has raised several challenges for the sustainable development of the FCT. 
Impact of Urbanization on Sustainable Development: The impact of rapid urbanization on human settlements has both positive and negative effects, but more often than not the negative impacts have consequences on sustainable development. Many scholars' researchers and professionals have undertaking research work on these subject and made interesting revelations.

Akolade (2007) undertook a study on the effect of urbanization on key economic, social and environmental variables on sustainable development in the urban areas of South-West Nigeria. He employed models based on the overall hypothesis that constraints on sustainable development in the urban areas of the region arise from low investment in socioeconomic infrastructure, high population density and poor quality of human capital. He concluded that in the urban areas of South-West Nigeria, the momentum of urbanization is accentuated by the previous level of growth of urban areas of the region, but not by level of investment in urban socio-economic infrastructure. Similarly, level of urban income and sustainable development are driven by their previous level while educational expansion or lack of it in the urban areas of the region is found to deteriorate the level of sustainable development in the area. It is also discovered that while the urban areas of Lagos State, are faced with the possible threat of over- urbanization, urban areas of Ogun and Oyo States can marginally accommodate increased urban growth that can contribute to increased level of sustainable development.

Khan (2008) conducted research on the challenges of sustainable development: rapid urbanization, poverty and capabilities in Bangladesh with the main purpose of examining the causes and consequences in particular, the policy implications of the ongoing urbanization in Bangladesh. He concluded that the urban population is growing faster than the rural population, at the same time, the labour force in nonagriculture is growing faster than the labour force in agriculture. But the employment opportunities in either sector are not growing adequately. His recommendations pinpoint, among other things, the need to build up productive capacities in order to create adequate employment and incomes for the rapidly growing population, particularly in the urban areas. The development of productive capacities, which is a precondition for the creation of productive employment opportunities, is a central element of viable poverty reduction strategy for Bangladesh as well. Without significant poverty reduction it is impossible to think of viable urbanization on the basis of sustainable development criteria.

Also Ejaro (2009) in his study on Urbanization and land cover change in the Federal Capital Territory (FCT), Abuja: issues and challenges for sustainable development, came to the conclusion that the impact of changes in land covers, consequent on urbanization, on the bio-geochemical environment calls for concern because it is an unsustainable development. This phenomenon also throws up other sustainable living challenges in the FCT such as slums, environmental degradation, traffic congestion, unemployment and crime.

Alagbe (2006) examined the challenges of rise in urban slums in cities in the developing world taking Lagos State, Nigeria, as his case study. He reviewed the historical development of Lagos State with a view to determining how it resulted into a megacity with inadequate level of infrastructural development to match its status, which subsequently gave rise to development of urban slums and squatter settlements within the metropolis. He concludes by stating that Lagos State has witnessed tremendous population growth rate from pre-independence to postindependence era, bringing with it attendant problems such as lack of infrastructures, lack of adequate and decent housing and social vices which are antithetical to sustainable development. His recommendations focused on how to improve infrastructural facilities, upgrade urban slums and squatter settlements without necessarily resulting into house demolitions or outright eviction of people from their abode.

Dawam and Ebehikhalu (2007) also assessed the impact of urbanization on the urban and rural environment of Nigeria. Their study examined the process of urban growth, cases and impact of urbanization on both the rural and urban environments of Nigeria. They concluded that rapid urbanization has the negative effect of depopulating the rural areas and degrading the urban areas. This poses the problem of poverty which is manifest in the form of slums, inadequate infrastructure, crimes, unemployment and low quality of life.

Nsiah-Gyabaah (2003) conducted research on Urbanization, environmental degradation and food security in Africa, in which he examined the urbanization process in Africa in the context of the

\section{*15UNDAY P. EJARO; AISHA ABUBAKAR}


environment, food supply and human security and also on the implications of rapid urbanization for sustainable development and human security in Africa. His paper draws attention to the socioeconomic and environmental implications of rapid urbanization and population growth in the developing countries with particular reference to Africa. He concluded that although urbanization is associated with unemployment, air and water pollution, congestion, overcrowding, social disturbances, crime, ethnic conflicts, environmental degradation, HIV/AIDS etc., it however provides opportunities for growth and development of markets for consumer goods and a source of human capital for managing natural resources. His recommendation was that there must be a decided move towards better planning and management which focus on cities with past failures giving way to more appropriate policies and practices. Proper land use planning, urban environmental monitoring and family planning are required to solve the problems of urbanization in Africa.

Capio and Fath (2011) undertook a research to assesses the direct effects of urban expansion on land cover/use, river flow, water quality and the indirect effects of these variables in the rate of gastrointestinal disease in people in Arequipa, Peru through the combined use of satellite remote sensing and geographic information systems. Results indicate that there has been notable urban growth and a loss in volcanic material land and cropland between 1990 and 2007, as new urban developments have appeared in these areas. The analysis also show a direct correlation between urbanization with the decrease of water quality and the increase in the incidence of gastrointestinal diseases.

Other notable literature on this subject include among others; Giok Ling and Hung Phua 2008; Green 2010; Kelly 1988; Oladipupo, 2007; Onibokun 1990; Panayotou 1994; Salau 1990; Taylor, 1986.

Nigeria Federal Capital City, Abuja: The Federal Capital City (FCC), Abuja was created in 1976 as the new seat of government of Nigeria. The crescent shaped city occupies just 250 square kilometres of the 8000 square kilometres of the Federal Capital Territory (FCT). However, it was in 1991 the seat of government officially moved to Abuja. At inception, Abuja was planned in phases in accordance with the regional master plan prepared by Doxiadis Associates Ltd in 1978 in a joint venture with Wallace, Roberts and Todd (WRT) of America. Each phase was targeted towards a specific population. The city was planned in four phases over a twenty five year period. The twenty five year period has since elapsed but development has just entered the third phase. The implication of development not being at par with planned population is a vexing challenge to the development of Abuja. Even the other towns in the Federal Capital Territory which are integrated into the regional plan as satellite towns to cater for the people who can't reside in the city have not been appropriately developed because the Satellite Towns Development Agency has failed in discharging its mandate.

The population of Abuja has been steadily growing since its movement from Lagos. It has grown phenomenally from 113,000 in 1976, 378,671 in 1991 to 1.4 million in 2006 (NPC, 2006). A greater part of this population, due to inadequate accommodation and high rents in the city, end up settling in the suburbs of the city; in areas such as Kubwa, karu Masaka, and Nyanya. The urban growth rate of suburbs such as Karu and Nyanya in 2001 was $66.2 \%$ compared to Abuja city which was $40.2 \%$ (Jinadu, 2004). This urban growth is worrisome, against the background that urban development and infrastructural plans are not as effectively planned and implemented leading to increased numbers of dwellers with little or no access to water, shelter, sanitization, education, health, etc.

The aim of this study is to examine the impact of rapid urbanization on the sustainable development of Nyanya, Abuja. The objectives of the study are; to profile infrastructural facilities and services available (health, education, transportation etc), to examine their state of utilization and challenges, review factors responsible for the rapid urbanization of Nyanya and evaluate the impact of rapid urbanization on the sustainable development of Nyanya.

The Study Area : Nyanya is a suburb of the Federal Capital Territory located in Abuja Municipal Area Council. It is about $12 \mathrm{~km}$ and a 10 minute drive from the city centre. Nyanya was a traditional Gwari settlement which like most traditional settlements of the FCT underwent urban renewal. It comprises of 4 sections; Nyanya phase I, Nyanya phase II, Nyanya phase IV and the Nyanya labour camp originally planned and developed to house low level public servants as temporary abode before they are allocated permanent housing in government 
developed estates (URP, FCDA, 1989). It covers an approximate area of $16.2 \mathrm{Sq} . \mathrm{km}$.

Nyanya is bordered on the north and north east by a range of hills, to the east and south east by Maraba district of Nasarawa state, to the south by Federal housing Karu site and to the west by Abuja city (Fig. $1)$.

In terms of structure of administration and management of Nyanya, it is administered by the
Abuja Municipal Area Council as a third tier of government. This is overseen by the Ministry of the Federal Capital Territory (MFCT). The MFCT has its agencies such as the Federal Capital Development Authority (FCDA) saddled with the mandate to develop the federal capital territory. The FCDA has organs such as the Satellite Towns Development Agency to develop the satellite towns such as Nyanya.

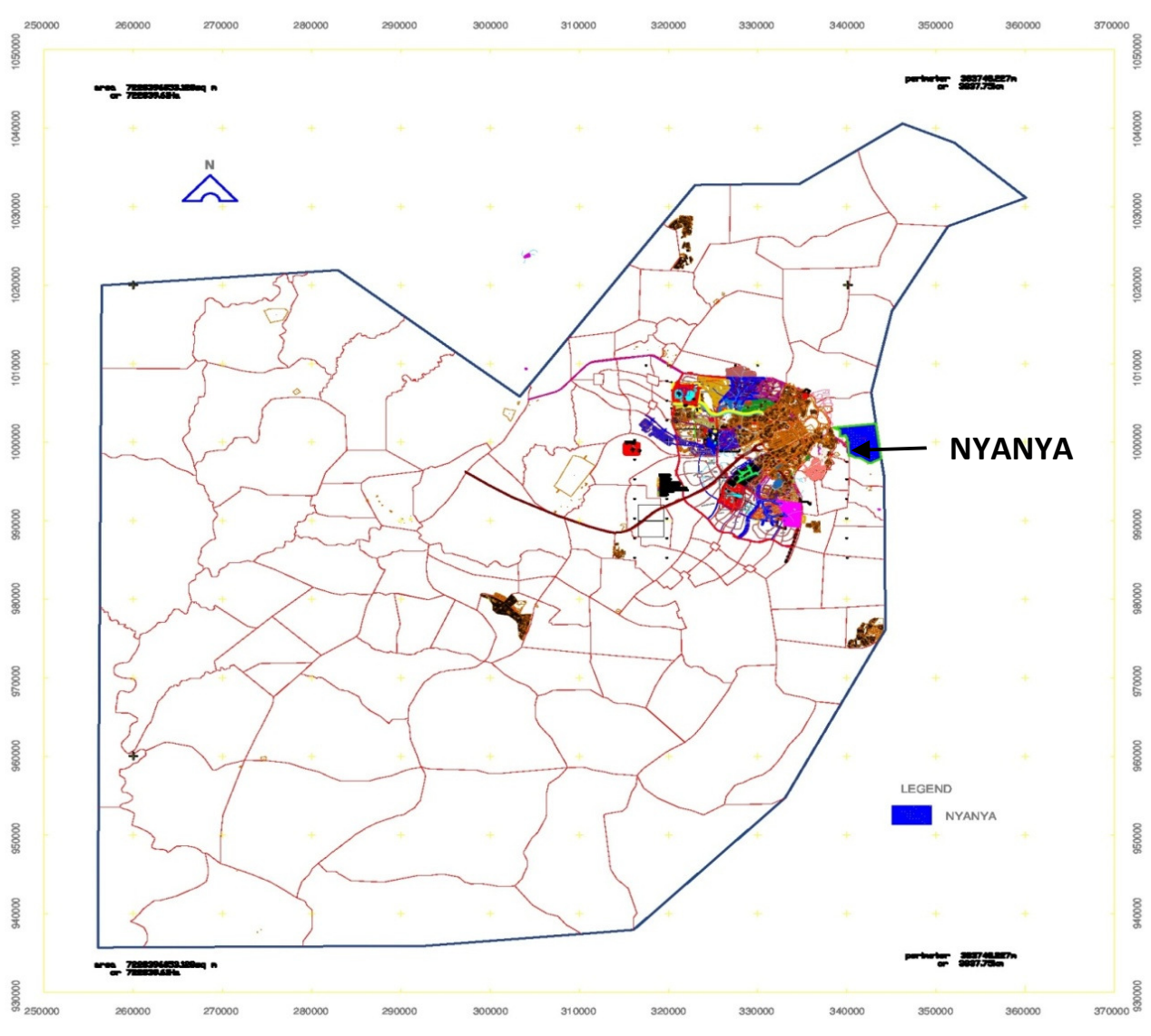

Fig. 1 Map of FCT, Abuja showing the FCC and Nyanya (the study area) Source: URP, FCDA

\section{MATERIALS AND METHOD}

Two land sat ETM (30M resolution) satellite data images covering Nyanya settlement for the years 2001 and 2010.

GIS software (ERDAS IMAGNE 8.6) was used for data processing and analysis.
Census data, migration and sentinel surveys from Nigeria National Population Commission (NPC).

Enumeration reports and baseline data reports from the Millennium Development Goals, Project support unit and the department of Urban and Regional planning, Federal Capital Development Authority (FCDA). 
Health and educational facilities data obtained from the FCDA Education Department and Health Services Department.

Satellite imagery was utilized in evaluating spatial and temporal changes that have occurred within the data set periods. This will enable the evaluation of the impact of rapid urbanization on the Nyanya environment. Data imagery was classified into land cover types adapting the Anderson classification system and change detection carried out using the post classification comparison algorithm. Classified images of the 2 selected years were cross referenced and results of change detection will be used for change detection analysis.

Field observations and Questionnaire was employed for gathering requisite data to profile infrastructural facilities and services available and to examine their state of utilization and challenges. Questionnaire administration was by stratified random sampling relative to the residential status of the residents. The first strata will include respondents residing within

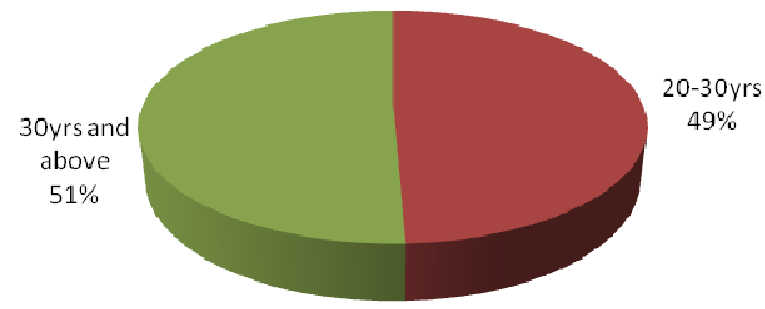

Fig 2. Age distribution of respondents

Figure 3 shows that $12 \%$ of the respondents attended primary school, 26\% attended secondary school, 33\% attended college or university for Bachelor's degree or diploma and $20 \%$ had post graduate level of education. The illiterate respondents constitute $9 \%$. permanent structures, while the second strata will include respondents of semi-permanent/makeshift residential status. 35 questionnaires each was administered in each of the six zones in Nyanya; 20 of the questionnaires were administered to residents residing in permanent structures while 15 to those residing within semi-permanent/makeshift structures. A total of 210 questionnaires were administered. Data obtained from the questionnaire will be analyzed statistically in order to assess the impact of rapid urbanization on the sustainable living of the population according to the United Nations' Human Development Index.

\section{RESULTS AND DISCUSSION}

Social and economic characteristics of espondents The relevant social characteristics of respondent to this study are age distribution and educational background. Figure 2 and figure 3 show the characteristics. This indicates mature, working class and literate respondents who understood the issues.

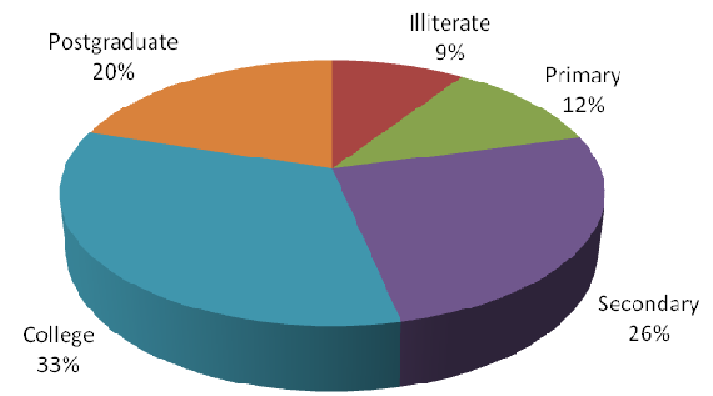

Fig 3 Educational background of respondents

The source of livelihood of respondents is shown in figure 4 . Public servants constitute $24 \%$, those who are self-employed either as artisans or own commercial enterprises are $30 \%$, those engaged by organized private sector and the non-governmental Organizations are $21 \%$, while all others not in the three earlier categories constitute $25 \%$. 


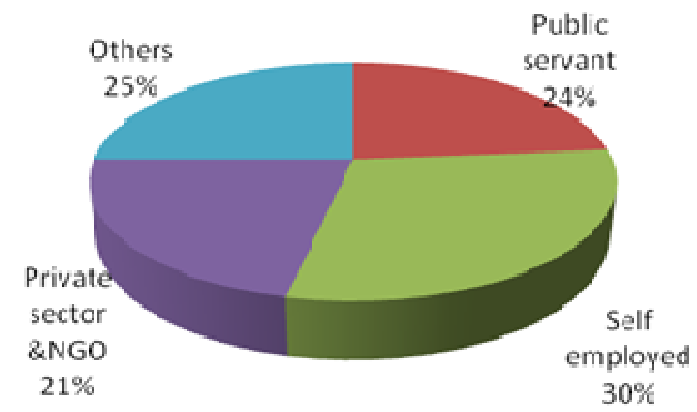

Fig 4 Source of livelihood of respondents

\section{Migration and rapid urbanization of} Nyanya: From figure 5, 73\% of the respondents moved to Nyanya between the years 2000-2011 and $27 \%$ moved to Nyanya between the periods of 19902000. This is consistent with the population figures of

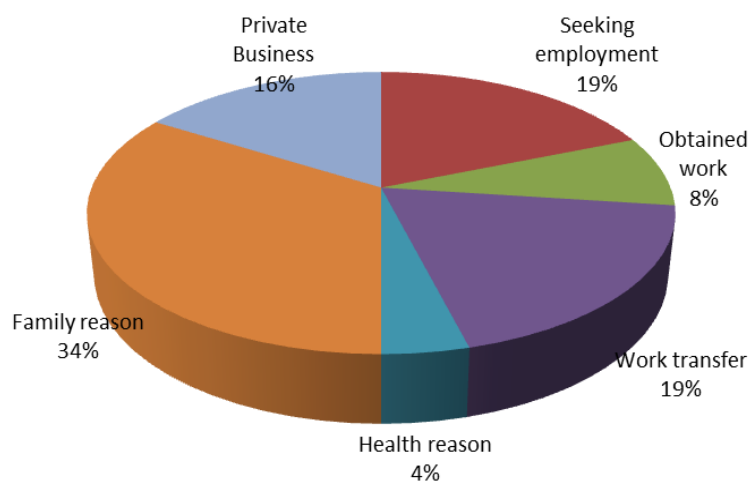

Fig 6 Migration to Nyanya

The reasons for migration to Nyanya are shown in figure $6.18 \%$ of respondents moved into Nyanya to seek for employment. About $8 \%$ of the respondents obtained employment, $4 \%$ moved for health reasons, $14 \%$ were on work transfer, $12 \%$ moved in to start a new business while $34 \%$ moved for family reasons.

Work Place Location: Figure 7 shows that respondents who work within Nyanya are just 21\%, Maraba-Masaka $17 \%$ and Abuja city $62 \%$. The majority of the respondents work in Abuja city. As

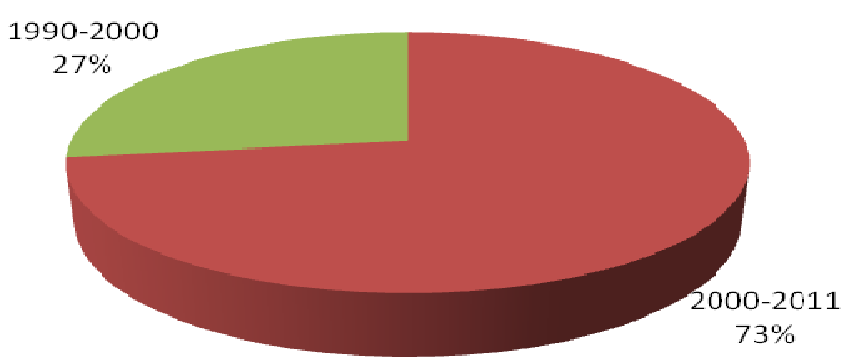

Fig 5 Reasons for migration to Nyanya

Nyanya. In 1991, Nyanya population was 20,278 (NPC, 1991) and in 2001, its population grew to 78,737 (Salako, 2001). The 2011 estimated population is 186,399 at $9 \%$ annual growth rate for the FCT. The primary factor responsible for the rapid urbanization of Nyanya is population rise especially between the years 2000 and 2011 (fig 5).

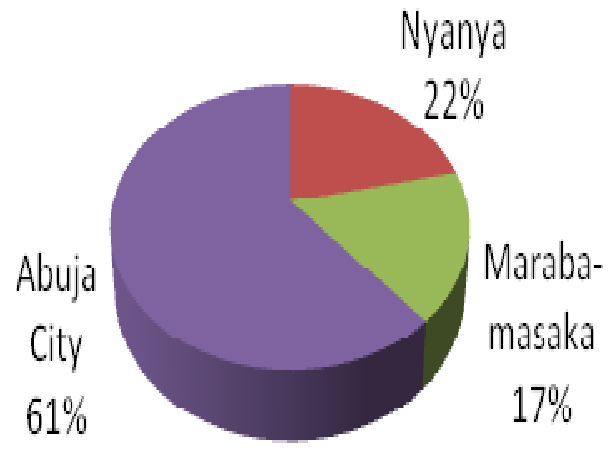

Fig 7 Work Place location

pointed out earlier, most of the residents of Nyanya are public servants, professionals and artisans who go to work in the city. They commute daily to the city where their offices, businesses and workshops are located. Maraba-Masaka suburb is a neighbouring area immediately after Nyanya, the study area.

Transport: Figure 8 represents the daily mode of transport to work. $27 \%$ of respondents go to work with their privately owned vehicles while $30 \%$ use the public mass transit bus. The public mass transit buses are the long buses with capacity of 45 
commuters. Respondents who use the mini-bus with capacity for ten commuter's buses are $20 \%$. Taxis transport $9 \%$ of the respondents. $14 \%$ of respondents trek to their various working places. The respondents who trek work within Nyanya or at close by Maraba suburb.

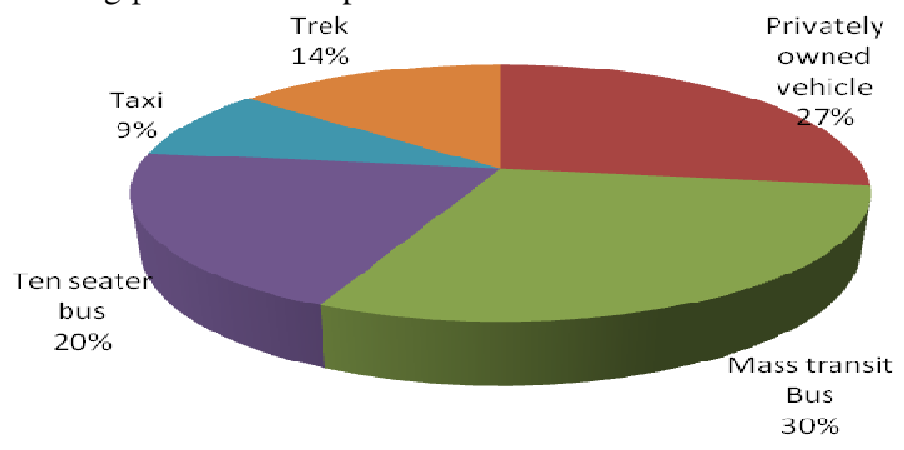

Fig 8 Mode of transport to work

Housing: The data on type of structures respondents are residing is presented in figure 9. In the diagram, $60 \%$ respondents are living in a permanent structure, while, $40 \%$ live in semi-permanent structures. The permanent structures are concrete block houses of different types with various types of amenities. They are considered modern and good. The semipermanent structures are patched up dilapidated buildings, uncompleted buildings and shanties. Facilities are lacking in most of these structures

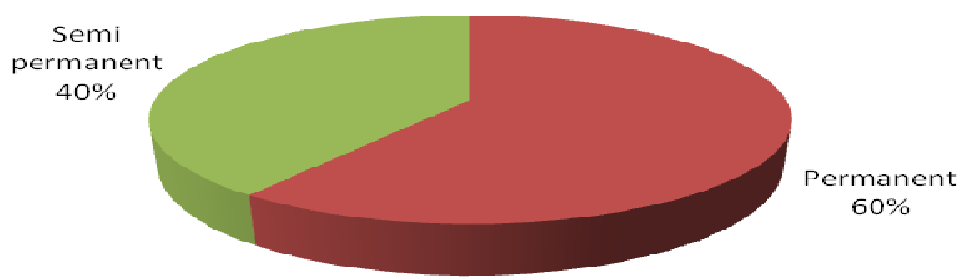

Fig 9 Type of structure respondents are residing

Data on residence status shown in figure 10 reveals that only $17 \%$ of respondents are owner-occupiers where they reside, while majority of the respondents $(61 \%)$ do not have houses of their own, they are tenants. 22\% respondents live with their friends \& family.

Data on residence status shown in figure 10 reveals that only $17 \%$ of respondents are owner-occupiers where they reside, while majority of the respondents $(61 \%)$ do not have houses of their own, they are tenants. $22 \%$ respondents live with their friends \& family.

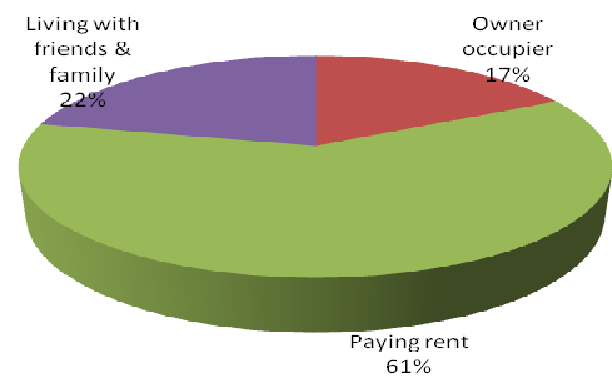

Fig 10 Residence status of respondents

Waste management: Only $22 \%$ of respondents have access to waste management facilities. The remaining $78 \%$ have no access (fig 11). 


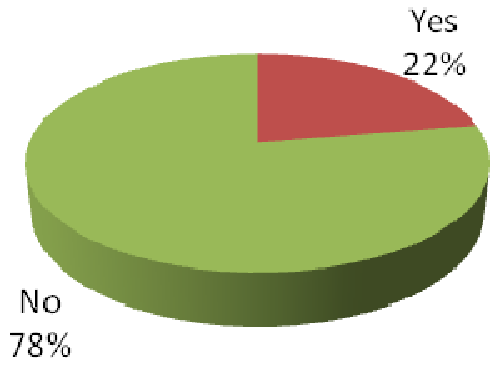

Fig 11 Access to waste management facilities

The $22 \%$ respondents are provided with waste storage bins by the Abuja Environmental protection Board (AEPB) and the agency collects the waste at intervals for disposal. Others provide their storage facilities and find ways of disposing their domestic waste. Figure 12 show the various methods disposal of domestic waste. The data indicate that $17 \%$ respondent's burn or incinerate the domestic waste they generate around their house. This causes air pollution and it is unhygienic. $21 \%$ of the respondents admit throwing domestic waste into street gutters. The health hazards of this practice are well documented in literature and this is what the residents expose themselves to. 22\% put it in AEPB

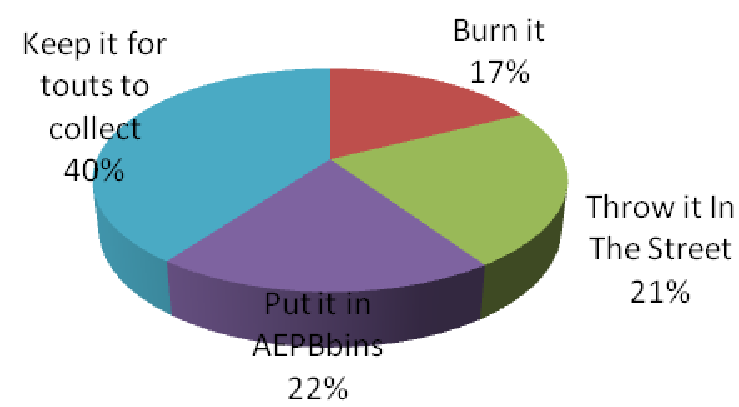

Fig 12 Methods of disposal of domestic waste

bins and wait for collection for proper disposal. $40 \%$ of the respondents keep the waste for touts or scavengers to collect and some end up in open dumps. Again these wastes at open dumps are incinerated. No land filling. It is common to find waste littered about on the streets, alleys and open spaces. The sights are eye sore and the smell oozing from these wastes unbearable. Yet residents get on with their lives with the consequent health hazards it poses.

Figure 13 represents the type of medical ailment experienced by respondents.

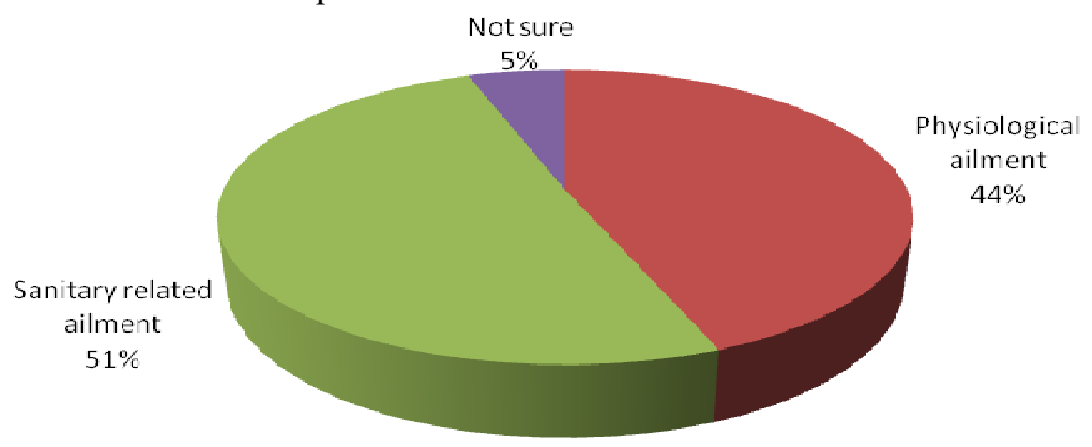

Fig 13 Type of Medical Ailment Experienced By Respondents Recently

From the study, $44 \%$ respondents were recently treated for a physiological ailment, while $51 \%$ respondents attended a health care facility due to a sanitary related ailment. 5\% respondents were not sure when last they were ill or why.

Access to public electric power supply: From figure 14 , only $3 \%$ respondents have 24 hours public electric power supply in their area daily, $17 \%$ respondents have less than 20hours public electric power supply per day, $42 \%$ respondents have electric power supply for less than 12hours daily, 33\% respondents have less than 5hours public electric power supply daily, and lastly, 5\% respondents do not have public electric power supply at all. Given this situation of dismal public electric power supply the impact is negative on productivity. The cost of supplementing power is high which leads to concomitant high cost of doing business. Petty artisans whose work require electricity and cannot afford the cost of providing their electricity are left idle for the period of absence of public electric power 
supply. This reduces productivity and also leads to frustration which ultimately leads to psychological disorder. With high rate of unemployment, this situation exacerbates it and leads to more crimes and social vices

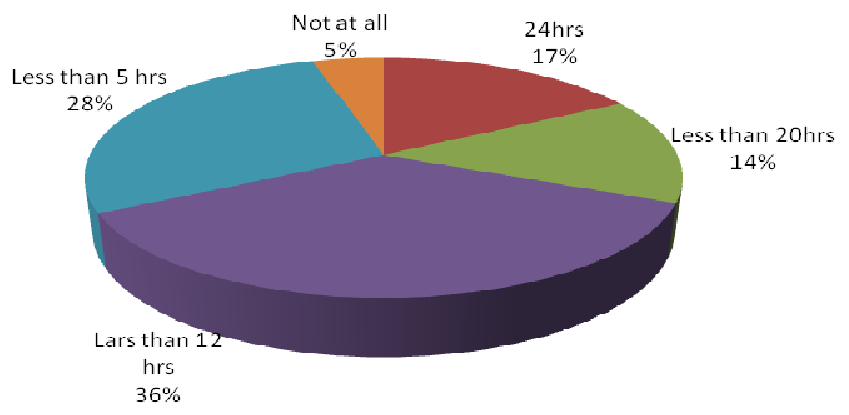

Fig 14 Access to public electric power supply

Domestic water supply: Data on sources of domestic water supply for residents of the study area is presented in figure 15 . In the diagram, only a paltry $6 \%$ have reliable and good pipe borne water from public water supply. $42 \%$ respondents depend on bore hole for domestic water. Of this $42 \%$, some actually sank the bore holes for their private use. Others sink the bore holes for commercial purposes to sell the water and residents purchase from them. $30 \%$ respondents obtain their domestic water from water vendors. These water vendors carry between 10 and 20 jerry cans of water in carts, each 20litres, hawking them from street to street. The quality of water sold by water vendors is not reliable. Finally, 22\% respondents source their source domestic water from hand dug wells.

Most of the sources of domestic water is not reliable. This exposes majority of residents to water borne diseases.

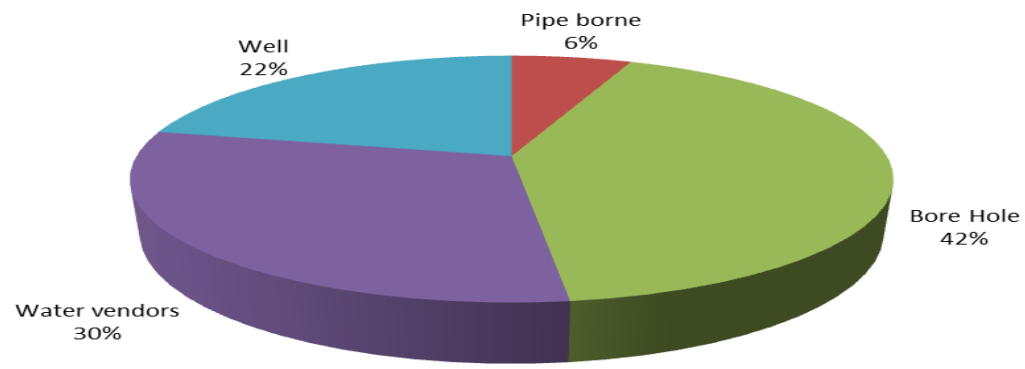

Fig 15 Source of domestic water supply

Access to Internet: It is interesting that the data on access to internet in figure 16 is encouraging in this ICT age. $40 \%$ of the respondents have access to internet facilities in their offices, cybercafés and some have their modems. $60 \%$ of the respondents do not have access to internet. Majority in this category are not computer literate. 


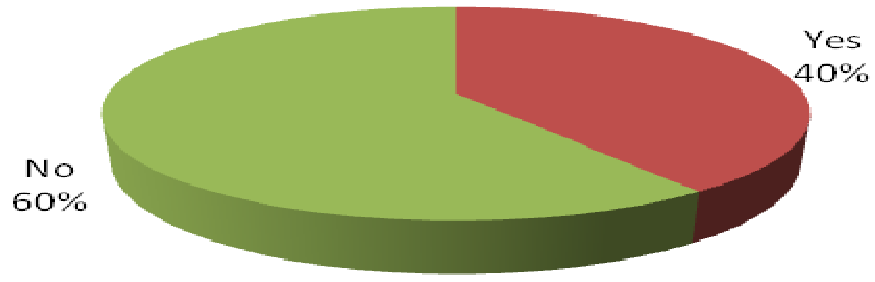

Fig 16 Access to internet

Health facilities:In the human development indices, health is a major indicator of sustainable development of a community. There are eleven (11) fully registered hospitals in Nyanya. Eight (8) are primary health care providers while three including Nyanya General Hospital provide secondary care. Only Nyanya General Hospital is a public or government owned hospital. There is a private but NGO clinic owned by a Christian religious body. All the other 9 are private health facilities. In terms of patronage, figure 17 , show that $57 \%$ respondents

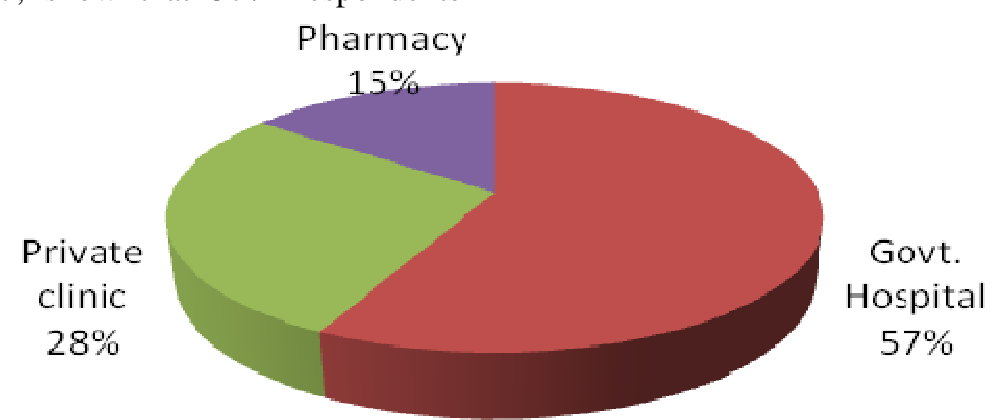

patronize the government hospital. This is understandable because the cost is affordable. 28\% respondents patronize private clinics. $15 \%$ respondents still indulge in unwholesome practice of patronizing pharmacy shops. Often these types of respondent engage in self-medication or patronize quack medical personnel in such pharmacy shops. The danger of such unwholesome practices is that it leads to complications and sometimes results in deaths.

Fig 17 Type of health care facility attended by respondents

Educational facilities: Another major human development index for sustainable development of a community is education. From the study, a total of 16 educational facilities are located within Nyanya. There are 3 government secondary schools and 2 government primary schools. Eleven (11) are fully accredited private schools; of which, 2 are basic secondary schools and 9 are primary/kindergarten schools. In terms of carrying capacity and quality, the educational facilities at Nyanya are inadequate. This is why parents send their children to schools outside Nyanya. Figure 18 present the location of children's educational institutions. Though 50\% of the parents send their children to schools within Nyanya, 31\% take their children to Abuja city where they consider the standard high. 19\% of the respondents who could not find space for their children take them to the neighbouring Maraba-Masaka suburb. 


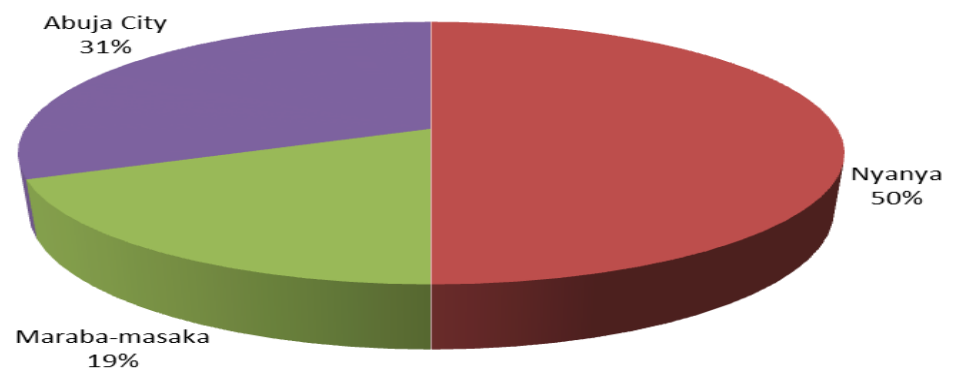

Fig 18 Location of Children's Educational Institution

Rapid urbanization and impact on Land Use Land Cover Change: Using satellite imagery for the years 2001 and 2011, land use/land cover (LULC) change data was analyzed in five categories: Built- up land/ new development areas, rock outcrop/barren land, dense vegetation, grassland, parks and gardens and water bodies. The land use/land cover distribution for the two date sets is presented in table 1 .

Table 1: Land use/ land cover distribution for 2001 and 2011

\begin{tabular}{|l|l|l|l|l|l|l|}
\hline S/No & LULC Category & $\begin{array}{l}\mathbf{2 0 0 1} \\
\text { Area }\left(\mathbf{k m}^{2}\right)\end{array}$ & $\begin{array}{l}\mathbf{2 0 0 1} \\
\text { Area }(\%)\end{array}$ & $\begin{array}{l}\mathbf{2 0 1 1} \\
\text { Area }\left(\mathbf{k m}^{2}\right. \\
)\end{array}$ & $\begin{array}{l}\mathbf{2 0 1 1} \\
\text { Area }(\%)\end{array}$ & $\begin{array}{l}\text { \% } \\
\text { Rate of } \\
\text { Change }\end{array}$ \\
\hline 1 & $\begin{array}{l}\text { Built-up land/new } \\
\text { development areas }\end{array}$ & 6.37 & 39.60 & 10.19 & 63.34 & +59.97 \\
\hline 2 & $\begin{array}{l}\text { Rock outcrop } \\
\text { /barren land }\end{array}$ & 2.58 & 15.99 & 1.23 & 7.62 & -52.33 \\
\hline 3 & Dense vegetation & 2.80 & 17.37 & 2.67 & 16.61 & -4.64 \\
\hline 4 & Grassland, parks \&gardens & 4.34 & 26.98 & 1.99 & 12.37 & -54.15 \\
\hline 5 & Water bodies & 0.11 & 0.06 & 0.12 & 0.06 & +9.00 \\
\hline & Total & 16.20 & 100.00 & 16.20 & 100.00 & \\
\hline
\end{tabular}

Source: Authors, 2013

The impact of rapid urbanization can be seen in the LULC distribution and rate of change. The major change that occurred in the LULC of Nyanya was in built-up land/new development areas. This category increased from $6.37\left(\mathrm{~km}^{2}\right)$ i.e. $39.60 \%$ in 2001 to $10.19\left(\mathrm{~km}^{2}\right)$ i.e. $63.34 \%$ in 2011 at $59.97 \%$ rate of changes. This increase was to accommodate the increased population and the demand for land for housing and infrastructural development. This consequently led to losses in rock outcrop/barren land, dense vegetation and grassland, parks and gardens categories.

Rapid urbanization and its impact on infrastructural facilities and services: As pointed out earlier, the rapid urbanization of Nyanya is as a result of substantial migration rather than a gradual urbanization process which would have witness gradual transformation of social, economic and infrastructural facilities and services. The consequence of this rapid urbanization and population rise within a short period is that infrastructural facilities and services are grossly inadequate to cater for the population. The profile of infrastructural facilities in the previous section attests to this challenge. This ultimately has negative impact on the living standard of the people and the environment. The study reveals that there is inadequate good quality housing, poor waste management facilities, inadequate electric power supply, inadequate good quality domestic water supply, inadequate and unaffordable health care facilities, poor environmental health and traffic congestion on the Abuja city-Nyanya-Maraba-Keffi 
road. These challenges do not commend Nyanya as a satellite town on the path of sustainable urban development. The Abuja Satellite Towns Development Authority should as a matter of urgency ensure a qualitative built urban environment with adequate resources and facilities to support a sustainable healthy living and economic progress of the residents of Nyanya.

Summary and conclusion: The study examined the impact of rapid urbanization on the sustainable development of Nyanya. Primary data through questionnaires administration was employed to obtain data on demography, housing, transport and other infrastructural facilities available, their state of utilization and challenges. Secondary data was obtained from the National Population Commission and Urban and Regional Planning Department Enumeration reports on Nyanya. Two land sat ETM (30M resolution) satellite data images covering Nyanya suburb for the years 2001 and 2011 were utilized to analyze the impact of rapid urbanization on land use and land cover change. One major finding of the study is that the primary factor for the rapid urbanization of Nyanya within a short period of time is migration. The consequence of this rapid urbanization and population rise is that infrastructural facilities and services are grossly inadequate to cater for the population.

The impact of this rapid urbanization on Nyanya is not all gloom. It has its positive impact on the economy. Artisans, traders or commercial enterprises and housing construction professionals are enjoying a boom in their businesses. On the negative impact, the study reveals that there is inadequate good quality housing, poor waste management facilities, inadequate electric power supply, inadequate good quality domestic water supply, inadequate and unaffordable health care facilities, poor environmental health, and traffic congestion especially on the Abuja city-Nyanya-Maraba-Keffi road. These challenges do not commend Nyanya as a satellite town on the path of sustainable urban development. The Abuja Satellite Towns Development Authority should as a matter of urgency to ensure a qualitative built urban environment with adequate resources and facilities to support a sustainable healthy living and economic progress of the residents of Nyanya.
Recommendations: The following recommendations are proffered for the sustainable development of Nyanya.

There is urgent need for the Federal Capital Development Authority (FCDA) to embark on urban renewal of Nyanya. Adequate infrastructural facilities and services should be provided for the residents. Mechanism for periodic review and upgrading should be put in place.

The Satellite Towns Development Agency (an agency of FCDA) should as a matter of urgency wake up to its mandate to maintain a qualitative built urban environment with adequate resources and facilities to support a sustainable healthy living and economic progress of the residents of Nyanya.

The Abuja Municipal Council Area should explore the option of commissioning private waste management companies to handle the waste management of Nyanya.

The Ministry of FCT should develop and sustain an ingenuous land policy that will encourage private property developers to build affordable housing for the lower income earners to address the issue of housing for the lower income earners. This policy could be implemented, using incentives. When implemented it will not only solve the housing issue of Nyanya but also provide much needed revenue for the Federal Capital Territory.

The Ministry of FCT should construct a by-pass around Nyanya- Maraba to ease the traffic congestion on the existing road.

\section{REFERENCES}

Akolade, G. O (2007), Effect of Urbanization on Sustainable Development in South-West Nigeria; PhD Research, unpublished, Department of Economics, University of Lagos, Nigeria

Agbola, T. (2005) Urbanization, Physical Planning and Urban Development in West Africa

Proceedings of Commonwealth Association of Planners Congress Agenda Setting Workshop on Urbanization, Physical Planning and Urban Development in West Africa.held at Millenium Hotel, Sokode Crescent, Wuse Zone 6, Abuja, Nigeria pp 40-67

Alagbe, O. A (2006), Challenges of Rise in Urban Slums in Cities in Developing World: A Case

\section{*'1SUNDAY P. EJARO; AISHA ABUBAKAR}


Study of Lagos State, paper presented at the international conference on The Built Environment: Innovation Policy \& sustainable Development, Covenant University, Ota, Ogun; January 24-26

Ankerl, Guy (1986). Urbanization Overspeed in Tropical Africa. INU PRESS, Geneva. ISBN 2$\underline{88155-000-2}$

Capio, O. V. and Fath, B.D. (2011) Assessing the Environmental Impacts of urban Growth

Using Land use/Land Cover, water Quality and Health Indicators: A Case Study of Arequipa, Peru. American Journal of Environmental Sciences 7(2): 90-101

Cincotta, R.P. and Engelman, R. (1997) Economics and Rapid Change: The Influence of Population Growth. http://populationaction.org/wpcontent/uploads/2012/01/Economics_And_Rapid _Change_PDF.pdf

Cohen, B. (2006), Urbanization in Developing Countries. Technology in society, vol. 28, pp. 6380

Dawam, P. D and Ebehikhalu, O. N (2007), The Impact Of Urbanization On Nigerian Environment, Urbanization Resource Exploitation And Environmental Stability In Nigeria; Book Of Proceedings Of The 49th Annual Conference of The Association Of Nigerian Geographers (ANG), 15-19 October 2007

Dogan, M. and Kasarda, J.D (eds) (1989) The metropolis Era Vol.1 The World of Giant Cities. Sage Publications. New York.

Ejaro, S.P (2009). Uurbanization and land cover change in the federal capital territory, Abuja. Issues and challenges for sustainable development, Journal of Economics and Allied Fields; vol 4,1,14-17

, J.B.(2005) Needs and Opportunities for Meeting Challenges of Urban Development in West

African Sub-Region. Proceedings of Commonwealth Association of Planners Congress Agenda Setting Workshop on
Urbanization, Physical Planning And Urban Development in West Africa. Held at Millennium Hotel, Sokode Crescent, Wuse Zone 6, Abuja, Nigeria. pp 103-114

Hartshorn, T. ((1992), Interpreting the city: An Urban geography. John Wiley and Son Inc. New York

International Human Dimensions Programme on Global Environmental Change (IHDP) (2005)

Science Plan Urbanization and Global Environmental Change, IHDP; Report. No. 15.

Bonn.

Jinadu, A. M (2004), urban expansion and physical development problem in Abuja: implications for the national urban development policy. Journal of the Nigerian Institute of Town Planners. Vol. XVII pp 15-29

Khan, H. (2008), Challenges of sustainable Development: Rapid Urbanization, poverty and capabilities in Bangladesh, Munich Personal RePEc Archive, unpublished

National Population Commission (NPC) (2006), Facts And Figures 2006 census. Retrieved http//www.population.gov.ng

Nsiah-Gyabaah (2003), Urbanization, Environmental Degradation And Food Security In Africa Prepared For Poster Presentation At The Open Meeting Of The Global Environmental Change Research Community, Montreal, Canada, 16-18 October 2003.

Peng, X., Chen, X and Cheng, Y. (2000) Urbanization and its consequences. Demography-vol.II http://www.eolss.net/EolsssampleAllchapter.aspx

Salako, A. (2001) Nyanya Solid Waste Management Pilot Project: Final Report on Property Enumeration for the Federal Ministry of Environment and the AEPB. Published by Computronic Technologies Ltd, Lagos.

United Nations Population Funds (UNFPA) (2007), State Of The World Population And World Population Prospects. Unleashing the Potential of Urban Growth. http://web.unfpa.org/swp/2007/english/chapter_1 /urbanization.html. 
UN Habitat (2006), state of the world's cities; ISBN 92/1/131811-4. UN habitat. Retrieved from: www.unhabitat.org
URP, FCDA (1989), Nyanya Urban Renewal: Report On Nyanya Labor Camp Relocation FCDA/URP/EST/159/137 